\title{
PENGARUH KEPATUHAN DAN SANKSI PERPAJAKAN TERHADAP PERENCANAAN PAJAK (TAX PLANNING) PADA WAJIB PAJAK BADAN YANG TERDAFTAR DI KPP PRATAMA BANDUNG BOJONAGARA
}

\author{
Rima Sundari ${ }^{1}$, Y. Casmadi ${ }^{2}$, Surya R. Noor ${ }^{3}$ \\ ${ }^{1}$ Prodi D-4 Akuntansi Keuangan, Politeknik Pos Indonesia, Kota Bandung, Indonesia \\ ${ }^{2,3}$ Prodi D-3 Akuntansi Keuangan, Politeknik Pos Indonesia, Kota Bandung, Indonesia \\ Email Korespondensi: rimasundari@poltekpos.ac.id
}

\begin{abstract}
Today many companies are making various efforts to reduce their taxes, these efforts are called tax planning. Tax planning can lead to tax planning that is legal and illegal. Illegal tax planning will be avoided if taxpayers are in compliance with tax regulations and taxpayers are aware of applicable tax sanctions. Likewise, if we do not comply with these regulations, they will be subject to sanctions. Based on this phenomenon, the researcher is interested to find out more about the problem in more depth by involving the taxpayers as the perpetrators of the problem so that it can provide a clearer picture of how tax compliance, tax sanctions and tax planning that occur in taxpayers who registered at the Tax Office (KPP) Pratama Bandung Bojonagara. Based on the research that has been done, the result that can be concluded is that there is an influence between tax compliance and sanctions on tax planning both partially and simultaneously.
\end{abstract}

Keywords: Tax Compliance, Tax Sanctions, Tax Planning

\begin{abstract}
Abstrak: Dewasa ini banyak perusahaan yang melakukan berbagai upaya untuk memperkecil pajaknya, upaya tersebut disebut dengan perencanaan pajak. Perencaan pajak dapat mengarah kepada perencanaan pajak yang bersifat legal dan ilegal. Perencanaan pajak yang bersifat ilegal akan bisa dihindari apabila para wajib pajak memiliki kepatuhan atas peraturan perpajakan dan para wajib pajak paham akan sanksi perpajakan yang berlaku. Begitu pula apabila kita tidak patuh akan peraturan tersebut maka akan dikenakan sanksi. Berdasarkan fenomena tersebut, maka peneliti tertarik untuk mengetahui lebih jauh permasalahan tersebut secara lebih mendalam dengan melibatkan para wajib pajak sebagai pelaku dari permasalahan tersebut sehingga dapat memberikan gambaran yang lebih jelas mengenai bagaimana kepatuhan wajib pajak, sanksi perpajakan dan perencanaan pajak yang terjadi pada wajib pajak yang terdaftar di Kantor Pelayanan Pajak (KPP) Pratama Bandung Bojonagara. Berdasarkan penelitian yang telah dilakukan, hasil yang dapat disimpulkan adalah terdapat pengaruh antara kepatuhan dan sanksi perpajakan terhadap perencanaan pajak baik secara parsial maupun simultan.
\end{abstract}

Kata Kunci: Kepatuhan Perpajakan, Sanksi Perpajakan, Perencanaan Pajak 


\section{PENDAHULUAN}

Indonesia merupakan negara yang berkembang, dimana perkembangan yang terjadi pada seluruh bidang, salah satunya di bidang ekonomi. Berkembang nya perekonomian suatu negara sudah pasti didukung dengan berkembangnya pertumbuhan dunia usaha tetapi perkembangan ini tentu saja akan menimbulkan persaingan yang ketat diantara para pelaku usaha. Sehingga untuk mampu bertahan di dalam industry para pelaku usaha harus bisa mempertahankan eksistensi nya dengan cara selalu berusaha untuk memperoleh keuntungan yang sebesar-besarnya,

Dengan memperoleh keuntungan sebesar-besarnya maka para pelaku usaha baik perorangan ataupun perusahaan akan tetap bisa berjalan untuk menjalankan kegiatan operasional nya. Perusahaan pada saat berada di pasar atau industry yang sejenis tentu akan menemui berbagai kendala diantaranya akan bertemu dengan para pesaing, yang selalu berusaha merebut pasar yang bisa mengurangi penjualan bahkan keuntungan dari perusahaan.

Dalam usaha memperoleh keuntungan yang sebesar-besarnya biasanya perusahaan akan menggenjot penjualan dan menekan beban yang ada di perusahaan, tetapi apabila akan menekan beban harus dilaksanakan dengan bijak, agar tidak berefek terhadap penjualan. Keuntungan di sini bisa kita sebut laba atau laba bersih. Kasmir (2011:303) menyatakan bahwa pengertian laba bersih (Net Profit) merupakan laba yang telah dikurangi biaya- biaya yang merupakan beban perusahaan dalam suatu periode tertentu termasuk pajak. Sehingga perusahaan pada saat ingin memperoleh keuntungan sebesar-besarnya atau ingin memperoleh laba bersih yang tinggi maka diharuskan pula memperhatikan dari sisi penjualan, beban dan pajak.

Laba bersih meningkat bisa diakibatkan dari peningkatan penjualan, penurunan beban dan rendahnya pajak. Tetapi suatu perusahaan pada saat ingin menurunkan beban harus memperhatikan efeknya yang bisa berakibat penurunan penjualan perusahaan. Dan perusahaan juga harus memahami dengan perpajakan yang berlaku di Indonesia , berlaku secara progresif, yaitu apabila laba meningkat maka hutang pajak pun meningkat.

Seperti yang kita ketahui bahwa pajak adalah sebagai sumber penerimaan negara terbesar kurang lebih sebesar 80\%. Dimana penerimaan dari pajak ini digunakan oleh negara untuk membiayai pengeluaran pemerintah dan pembangunan infrastruktur dan lain-lain nya. Berikut definisi Pajak berdasarkan UU NO. 28 TAHUN 2007 ttg Ketentuan Umum dan Tata Cara Perpajakan (KUP), Pajak adalah kontribusi wajib kepada negara yang terutang oleh orang pribadi atau badan yang bersifat memaksa berdasarkan undang-undang, dengan tidak mendapatkan imbalan secara langsung dan digunakan untuk keperluan negara bagi sebesar-besarnya kemakmuran rakyat. Berdasarkan definisi di atas dapat dinyatakan bahwa imbalan atau kenikmatan yang diterima oleh pembayar pajak tidak akan diterima secara langsung dan bersifat memaksa,sehingga apabila dilanggar maka akan terkena sangsi. Dengan adanya pernyataan bahwa imbalan tidak akan diterima secara langsung maka hal itu lah yang menyebabkan para wajib pajak merasa tidak tertarik untuk membayar pajak. Atau jika membayar pajak pun nilai nya tidak akan sebesar hutang pajak yang harus dibayarkan 
ditambah lagi adanya suatu perencanaan pajak (Tax Planing) yang matang dengan tujuan untuk meminimalkan membayar hutang pajak. Permasalahan muncul apabila terjadi Tax Planing yang melanggar aturan perpajakan yang berlaku. Tax Planning merupakan upaya legal yang dilakukan wajib pajak dengan memanfaatkan hal-hal yang tidak diatur atau celah yang ada dalam undang-undang dan peraturan perpajakan (loopholes) (Darmayasa \& Hardika,2011)

Putusan MA No.2239K/PID.SUS/2012 tanggal 18 Desember 2012, Asian Agri dinyatakan kurang membayar pajak pada periode 2002-2005 senilai Rp 1,25 triliun dan denda $\operatorname{Rp~1,25~triliun.~Total~yang~harus~dibayarkan~} \operatorname{Rp} 2,5$ triliun. Metta menilai, kasus pajak perusahaan milik Sukanto Tanoto itu jelas terkategorikan tax evation (skema untuk memperkecil pajak yang terutang dengan cara melanggar ketentuan perpajakan). Indikasinya adalah adanya fakta tax planning meeting atau pertemuan perencanaan pajak. Putusan MA pun dinilai luput lantaran hanya menjerat manajer perpajakan Asian Agri, Suwir Laut, selama dua tahun penjara dengan masa percobaan tiga tahun. "Jelas kasus ini kasus tax evation. Ini yang bertahun-tahun berusaha disumirkan bahwa ini adalah tax avoidance (skema transaksi yang ditujukan untuk meminimalkan beban pajak dengan memanfaatkan kelemahan-kelemahan ketentuan pajak), bukan tax evation. Karena tax evation ini implikasinya pidana," tutur penulis buku Saksi Kunci yang mengupas laporan investigasi skandal pajak ini. (https://money.kompas.com/read/2014/01/24/1644374). Suryanti (2010) menemukan bahwa PT. Arta Design mealkukan Tax Planning untuk meminimalkan pembayaran pajak penghasilan dengan memanfaatkan celah undang-undang perpajakn dari segi biaya yang diperkenankan sebagai pengurang Penghasilan Kena Pajak. Kemudian, PT. Rajawali Dwi P melakukan Tax Planning dengan pemilihan metode pembelian dalam pembelian kendaraan dan akhirnya memilih menggunakan leasing dengan hak opsi sebagai laternatif pembelian 7 unit tuk baru agar dapat melakukan tax saving (penghematan pajak) (Chrisdianto \&Andrianto, 2009)

Fenomena di atas terjadi karena disebabkan oleh beberapa factor, factor pertama tidak adanya kepatuhan wajib pajak dalam memenuhi kewajiban perpajakan (tax compliance) dan tidak memahami sangsi yang akan dihadapi jika melanggar aturan perpajakan yang berlaku. Kesadaran individu, pebisnis dan perusahaan untuk membayar pajak sesuai dengan realitas yang ada masih rendah (Subagyo \& Oktavia, 2010). Rendahnya tingkat kepatuhan wajib pajak dan ketidak pahaman atas sangsi pajak akan menyebabkan menurunnya penerimaan negara melalui pajak yang tentu saja akan berdampak pada jalannya pembangunan di Indonesia.

Dengan adanya penerimaan pajak sebagai penerimaan terbesar bagi negara sudah barang tentu pemerintah melalui Direktorat Jendral Pajak akan selalu berusaha untuk meningkatkan atau memaksimalkan penerimaan pajak tersebut dengan berbagai cara dari tahun ke tahun dengan meningkatkan target penerimaan pajak setiap tahun nya. Tetapi hal ini tentu sangat bertentangan dengan aktifitas atau tujuan dari perusahaan yaitu untuk memperoleh laba sebesar-besarnya demi mensejahterakan pemilik dan demi menjamin kelangsungan hidup perusahaan.Sehingga perusahaan akan selalu berusaha untuk meminimalkan dalam membayar pajak dengan cara melakukan 
perencanaan pajak (Tax Planing) yang matang dan optimal. Perusahaan besar memiliki peluang lebih kecil dibandingkan perusahaan kecil dalam melakukan tax planning (Mills,et al., 1998).

Dalam melakukan Tax Planning diharapkan para wajib pajak sudah memahami dan mematuhi peraturan dan sangsi perpajakan yang berlaku mengingat system pemungutan pajak yang berlaku di Indonesia saat ini adalah Self Assesment System , sehingga dalam melaksanakan perhitungan, pembayaran dan pelaporan pajak berdasarkan kesadaran dari masing-masing wajib pajaknya sendiri.

Berdasarkan uraian diatas, peneliti tertarik akan fenomena yang dapat mengurangi penerimaan negara melalui praktik Tax Planning dalam suatu organisai/perusahaan, sehingga hal ini menarik untuk dijadikan sebagai bahan penelitian dengan pembahasan dengan judul "Pengaruh Kepatuhan dan Sangsi Perpajakan terhadap Perencanaan Pajak (Tax Planning) pada Wajib Pajak Badan yang terdaftar di Kantor Pelayanan Pajak (KPP) Pratama Bojonagara Bandung ”.

Berdasarkan latar belakang yang telah dipaparkan sebelumnya, maka Identifikasi masalah dalam penelitian ini adalah:

1. Bagaimana Pengaruh Kepatuhan Perpajakan terhadap Perencanaan Pajak (Tax Planning)?

2. Bagaimana Pengaruh Sangsi Perpajakan terhadap Perencanaan Pajak (Tax Planning)?

3. Bagaimana Pengaruh Kepatuhan dan Sangsi Perpajakan terhadap Perencanaan Pajak (Tax Planning)?

\section{TINJAUAN PUSTAKA}

\subsection{Pajak}

Para ahli memberikan batasan tentang pajak, diantaranya pengertian pajak yang dikemukakan oleh P.J.A. Adriani (1991:2) dalam R. Santoso Brotodiharjo:

"Pajak adalah iuran kepada Negara (yang dapat dipaksakan) yang terutang oleh yang wajib membayarnya menurut peraturan-peraturan, dengan tidak mendapat prestasi kembali, yang langsung ditunjuk, dan yang gunanya adalah untuk membiayai pengeluaran-pengeluran umum berhubung dengan tugas negara yang menyelenggarakan pemerintahan”.

Asas-asas pemungutan pajak sebagaimana dikemukakan oleh Adam Smith dalam bukunya An inquiri the nature of cause the wealth of nations menyatakan bahwa pemungutan pajak hendaknya didasarkan pada equality, certainty, convenience dan economy. Pemungutan pajak harus bersifat adil dan merata, yaitu pajak dikenakan kepada orang pribadi yang harus sebanding dengan kemampuan membayar pajak atau ability to pay dan sesuai dengan manfaat yang diterima. Adil maksudnya bahwa setiap Wajib Pajak menyumbangkan uang untuk pengeluaran pemerintah sebanding dengan kepentingan dan manfaat yang diminta. Penetapan pajak itu tidak ditentukan sewenang-wenang. Oleh karena itu, Wajib Pajak harus mengetahui secara jelas dan pasti besarnya pajak yang terutang, kapan harus dibayar, serta batas waktu pembayaran. 
Kapan wajib pajak itu harus membayar pajak sebaiknya sesuai dengan saat-saat yang tidak menyulitkan wajib pajak sebagai contoh saat wajib pajak memperoleh penghasilan. Sistem pemungutan ini disebut Pay as you earn. Secara ekonomi bahwa biaya pemungutan dan biaya pemenuhan kewajiban pajak bagi wajib pajak diharapkan seminim mungkin, demikian pula beban yang dipikul wajib pajak.

\subsection{Kepatuhan Pajak}

Safri Nurmantu (2006:148), mendefinisikan kepatuhan perpajakan adalah "suatu keadaan dimana wajib pajak memenuhi semua kewajiban perpajakan dan melaksanakan hak perpajakannya”. Kepatuhan wajib pajak dapat dibagi menjadi dua, yaitu kepatuhan pajak formal dan kepatuhan pajak material.

Wajib pajak patuh adalah wajib pajak yang ditetapkan oleh Direktorat Jenderal Pajak sebagai wajib pajak yang memenuhi kriteria tertentu dimaksud di dalam Peraturan Menteri Keuangan No.192/PMK.03/2007 tentang kriteria wajib pajak yang dapat diberikan pengembalian pendahuluan kelebihan pembayaran pajak.

Wajib pajak dengan kriteria tertentu yang selanjutnya disebut sebagai wajib pajak patuh adalah wajib pajak yang memenuihi persyaratan sebagai berikut:

a. Tepat waktu dalam menyampaikan Surat Pemberitahuan.

b. Tidak mempunyai tunggakan pajak untuk semua jenis pajak, kecuali tunggakan pajak yang telah memperoleh izin mengangsur atau menunda pembayaran pajak.

c. Laporan Keuangan diaudit oleh Akuntan Publik atau lembaga pengawasan keuangan pemerintah dengan pendapat Wajar Tanpa Pengecualian selama 3 (tiga) tahun berturut-turut.

\subsection{Sanksi Perpajakan}

Dalam undang-undang perpajakan dikenal dua macam saksi, yaitu sanksi administrasi dan sanksi pidana. Perbedaan sanksi administrasi dan sanksi pidana adalah (Mardiasmo, 2016:63):

- Sanksi Administrasi yaitu merupakan pembayaran kerugian kepada negara, khususnya yang berupa denda, bunga dan kenaikan

- Sanksi Pidana yaitu merupakan siksaan atau penderitaan. Merupakan alat terakhir atau benteng hokum yang digunakan fiscus agar norma perpajakan dipatuhi.

\subsection{Perencanaan Pajak (Tax Planning)}

Secara garis besar, perencanaan pajak (tax planning) adalah proses mengorganisasi usaha wajib pajak atau kelompok wajib pajak sedemikian rupa sehingga utang pajaknya, baik pajak penghasilan maupun pajak-pajak lainnya, berada dalam posisi yang paling minimal, sepanjang hal ini dimungkinkan baik oleh ketentuan peraturan perundang-undangan perpajakan maupun secara komersial.

Tujuan Perencanaan Pajak (Tax Planning) (C.Anwar, 2013)

1. Meminimalisasi beban pajak terutang. 
2. Memaksimalkan laba setelah pajak.

3. Meminimalkan terjadinya kejutan pajak (tax suprise) jika terjadi pemeriksaan pajak oleh fiksus.

4. Memenuhi kewajiban perpajakannya secara benar, efisien, dan efektif, sesuai dengan ketentuan perpajakan

Tax Planning dilakukan sejak saat berdiri, aktivitas manajemen sudah dimulai, banyak sekali tax management yang harus dilaksanakan. Pada saat perusahaan bubar atau pada saat WP orang pribadi meninggal, masalah pajaknya masih ada. Jadi pajak tidak habis karena WP meninggal, karena warisan-warisan ini oleh fiksus masih di otakatik.

Manfaat Perencanaan Pajak (C.Anwar, 2016)

1. Penghematan kas keluar, karena beban pajak yang merupakan unsur biaya dapat dikurangi.

2. Mengatur aliran kas masuk dan keluar (cash flow), karena dengan perencanaan pajak yang matang dapat diperkirakan kebutuhan kas untuk pajak, dan menentukan saat pembayaran sehingga perusahaan dapat menyusun anggaran kas secara lebih akurat.

Persyaratan Tax Planing yang baik (C.Anwar, 2016) :

1. Tidak melanggar ketentuan perpajakan.

2. Secara bisnis masuk akal (reasonable).

3. Didukung oleh bukti-bukti pendukung yang memadai

\section{METODE PENELITIAN}

Desain penelitian merupakan rancangan penelitian yang digunakan sebagai pedoman dalam melakukan proses penelitian. Jenis metode yang digunakan oleh penulis sekaligus peneliti dalam penelitian ini adalah metode kuantitatif. Sedangkan table operasionalnya dijelaskan dalam table berikut:

Tabel 1. Operasionalisasi Variabel

\begin{tabular}{|c|c|c|c|}
\hline Variabel & Indikator & Skala & Alat Analisis \\
\hline $\begin{array}{c}\text { Kepatuhan } \\
\text { Wajib Pajale (Y) } \\
\text { Kriteria WT Paruh } \\
\text { PMIK r No. } \\
\text { 192/PMIR.03/2007 }\end{array}$ & 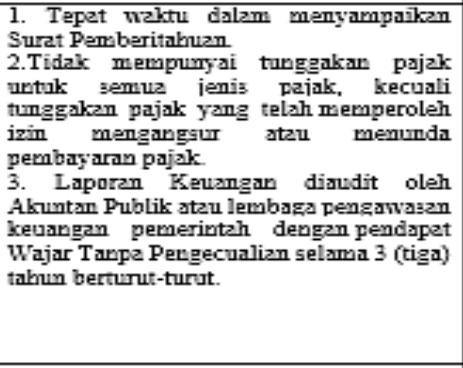 & Likert & $\begin{array}{l}\text { 1. Uji Normalitas } \\
\text { 2. Uji Validitas } \\
\text { 3. Uji Reliabilitas } \\
\text { 4. Analisis Korelasi } \\
\text { pearson Product } \\
\text { Moment } \\
\text { 5. Analisis Korelasi } \\
\text { Berganda } \\
\text { 6. Analisis Regresi } \\
\text { 7. Berganda } \\
\text { Boefisien } \\
\text { 8. Uiit } \\
\text { 9. Uji F }\end{array}$ \\
\hline \begin{tabular}{l}
\multicolumn{1}{c}{ Sanksi } \\
Perpajalian $\left(\mathrm{X}_{2}\right)$ \\
Nardiasmo \\
$(2016: 63)$
\end{tabular} & $\begin{array}{l}\text { 1. Sanksi Ad̆niniatrasi } \\
\text { 2. Sanksi Pidanz }\end{array}$ & Likert & $\begin{array}{l}\text { 1. Uji Normalitas } \\
\text { 2. Uji Validitas } \\
\text { 3. Uji Reliabilitas } \\
\text { 4. Analisis Korelasi } \\
\text { Pearson Product } \\
\text { Moment } \\
\text { 5. Analisis Korelasi } \\
\text { Berganda } \\
\text { 6. Analisis Regresi } \\
\text { Berpanda } \\
\text { 7. Koefisien } \\
\text { Determinzai } \\
\text { 8. Uji t } \\
\text { 9. Uji F }\end{array}$ \\
\hline
\end{tabular}




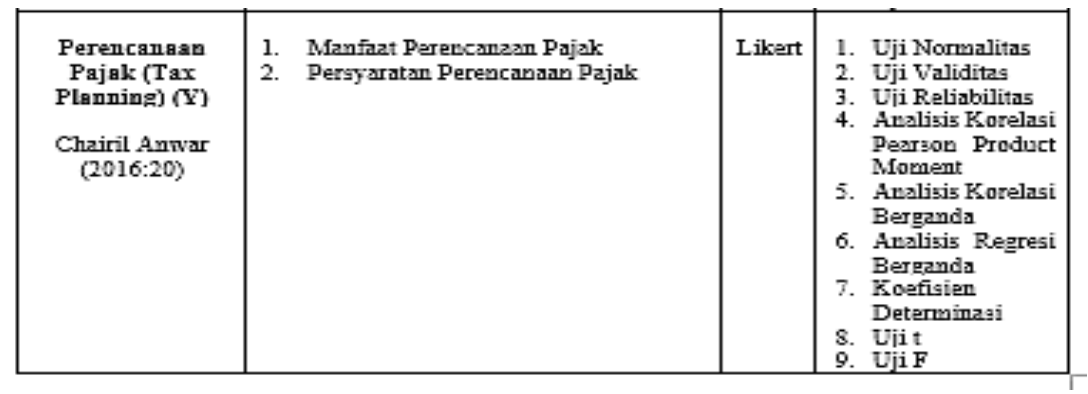

Skala pengukuran instrumen dalam penelitian ini menggunakan skala likert.

Populasi dalam penelitian ini adalah wajib pajak yang melaporkan pajak penghasilan badan pada KPP Pratama Bandung Bojonagara. Penelitian ini menggunakan teknik Nonprobability Sampling yaitu Teknik Sampling Insidental.

Penelitian ini menggunakan teknik Nonprobability Sampling yaitu Teknik Sampling Insidental. Sugiyono (2017:85) menyatakan "Teknik sampling insidental adalah teknik penentuan sampel berdasarkan kebetulan, yaitu siapa saja yang secara kebetulan/insidental bertemu dengan peneliti dapat digunakan sebagai sampel, bila dipandang orang yang ditemui itu cocok sebagai sumber data".

Roscoe dalam Sugiyono (2017:74) memberikan saran-saran tentang ukuran sampel untuk penelitian seperti berikut ini:

1. Ukuran sampel yang layak dalam penelitian adalah antara 30 sampai dengan 500 .

2. Bila sampel dibagi dalam kategori (misalnya: pria wanita, pegawai negeri-swasta dan lain-lain) maka jumlah anggota sampel setiap kategori minimal 30.

3. Bila dalam penelitian akan melakukan analisis dengan multivariate (korelasi atau regresi ganda misalnya), maka jumlah anggota sampel minimal 10 kali dari jumlah variabel yang diteliti. Misalnya variabel penelitiannya ada 5 (independen + dependen), maka jumla anggota sampelnya $=10 \times 5=50$.

4. Untuk penelitian eksperimen yang sederhana, yang menggunakan kelompok eksperimen dan kelompok kontrol, maka jumlah anggota sampel masing-masing kelompok antara $10 \mathrm{~s} / \mathrm{d} 20$.

Pada penelitian ini sampel yang digunakan sebanyak 58 sampel serta dikumpulkan datanya melalui kuesioner dan wawancara.

Teknik analisis data yang dilakukan yang pertama kali adalah menguji validitas, reliabilitas serta normalitas. Setelah itu dilakukan uji korelasi dan regresi linear berganda.

\section{HASIL DAN PEMBAHASAN}

\subsection{Hasil Uji Validitas}

Berikut ini adalah hasil Uji Validitas dpenelitian setiap variabel dalam instrument penelitian : 
Tabel 2. Uji Validitas X1

\begin{tabular}{|c|c|c|c|c|}
\hline $\begin{array}{c}\text { Pertanyaan } \\
\text { Variabel XI }\end{array}$ & $\begin{array}{c}\text { Nilai Uji } \\
\text { Validitas }\end{array}$ & $\begin{array}{c}\text { Syarat } \\
\text { Analisis }\end{array}$ & $\begin{array}{c}\text { Hasil Uji } \\
\text { Validitas }\end{array}$ & Kesimpulan \\
\hline 1 & 0.732 & 0,3 & $0,732>0,3$ & Valid \\
\hline 2 & 0.743 & 0,3 & $0,743>0.3$ & Valid \\
\hline 3 & 0.767 & 0,3 & $0,743>0.3$ & Valid \\
\hline 4 & 0.549 & 0,3 & $0.549>0.3$ & Valid \\
\hline
\end{tabular}

Tabel 3. Uji Validitas X2

\begin{tabular}{|c|c|c|c|c|}
\hline $\begin{array}{c}\text { Pertanyaan } \\
\text { Variabel X2 }\end{array}$ & $\begin{array}{c}\text { Nilai Uji } \\
\text { Validitas }\end{array}$ & $\begin{array}{c}\text { Syarat } \\
\text { Analisis }\end{array}$ & $\begin{array}{c}\text { Hasil Uji } \\
\text { Validitas }\end{array}$ & Kesimpulan \\
\hline 5 & 0.844 & 0,3 & $0.844>0,3$ & Valid \\
\hline 6 & 0.894 & 0,3 & $0.894>0.3$ & Valid \\
\hline
\end{tabular}

Tabel 4. Uji Validitas Y

\begin{tabular}{|c|c|c|c|c|}
\hline $\begin{array}{c}\text { Pertanyaan } \\
\text { Variabel Y }\end{array}$ & $\begin{array}{c}\text { Nilai Uji } \\
\text { Validitas }\end{array}$ & $\begin{array}{c}\text { Syarat } \\
\text { Analisis }\end{array}$ & $\begin{array}{c}\text { Hasil Uji } \\
\text { Validitas }\end{array}$ & Kesimpulan \\
\hline 7 & 0.739 & 0,3 & $0,739>0,3$ & Valid \\
\hline 8 & 0.845 & 0,3 & $0,845>0.3$ & Valid \\
\hline 9 & 0.737 & 0,3 & $0,737>0.3$ & Valid \\
\hline 10 & 0.794 & 0,3 & $0.794>0.3$ & Valid \\
\hline
\end{tabular}
Sumber: Diolah melalui program SPSS 23.0

\subsection{Hasil Uji Reliabilitas}

Tabel 5. Uji Reliabilitas

\begin{tabular}{|c|c|c|}
\hline Variabel & $\begin{array}{c}\text { Cronbach's } \\
\text { Alpha }\end{array}$ & $\mathrm{N}$ of Items \\
\hline Kepatuhan Wajib Pajak Badan $\left(\mathrm{X}_{1}\right)$ & .642 & 4 \\
\hline Sanksi Wajib Pajak Badan $\left(\mathrm{X}_{2}\right)$ & .672 & 2 \\
\hline Perencanaan Pajak $(\mathrm{Y})$ & .783 & 4 \\
\hline
\end{tabular}

Berdasarkan tabel diatas seluruh variabel telah memenuhi kriteria nilai Cornbach's Alpha > Cornbach's Alpha Standard $(0,60)$. Sehingga dapat dikatakan bahwa hasil jawaban layak dan konsisten dalam mengukur apa yang hendak diukur atau reliabel.

\subsection{Hasil Uji Normalitas}

Tabel 6. Uji Normalitas Kolmogorov-Smirnov

\begin{tabular}{|ll|r|}
\hline & & $\begin{array}{r}\text { Unstandardi } \\
\text { zed Residual }\end{array}$ \\
\hline $\mathrm{N}$ & & 58 \\
Normal Parameters ${ }^{\mathrm{a}, \mathrm{b}}$ & Mean & .0000000 \\
& Std. & 1.59271941 \\
& Deviation & .073 \\
Most Extreme & Absolute & .073 \\
Differences & Positive & -.067 \\
& Negative & .073 \\
Test Statistic & & .200 \\
Asymp. Sig. (2-tailed) & & \\
\hline
\end{tabular}

Sumber : Diolah melalui program SPSS

Berdasarkan tabel diatas dapat diketahui bahwa nilai signifikansi Asymp. Sig. (2tailed) sebesar 0,200. Berdasarkan hasil tersebut nilai residual dari ketiga variabel telah 
berdistribusi normal karena 0,200 > 0,05. Hal tersebut menunjukan secara perhitungan statistik bahwa data yang diteliti telah memenuhi asumsi normalitas.

\subsection{Analisis Korelasi}

Tabel 7. Uji Korelasi X1 -Y

\begin{tabular}{|c|c|c|c|}
\hline & & $\begin{array}{l}\text { Kepatuhan Wajib } \\
\text { Pajak Badan }\end{array}$ & $\begin{array}{l}\text { Perencanaan } \\
\text { Pajak (Tax } \\
\text { Planning) }\end{array}$ \\
\hline $\begin{array}{l}\text { Kepatuhan Wajib Pajak } \\
\text { Badan }\end{array}$ & $\begin{array}{l}\text { Pearson Correlation } \\
\text { Sig. (2-tailed) } \\
\mathrm{N} \\
\end{array}$ & 58 & $\begin{array}{l}.497^{* *} \\
.000 \\
58 \\
\end{array}$ \\
\hline $\begin{array}{l}\text { Perencanaan Pajak (Tax } \\
\text { Planning) }\end{array}$ & $\begin{array}{l}\text { Pearson Correlation } \\
\text { Sig. (2-tailed) } \\
\mathrm{N}\end{array}$ & \begin{tabular}{|l}
$.497^{* *}$ \\
.000 \\
58
\end{tabular} & $\begin{array}{l}1 \\
58\end{array}$ \\
\hline
\end{tabular}

Sumber: Diolah melalui program SPSS 23.0

Tabel 8. Uji Korelasi X2 -Y

\begin{tabular}{|ll|l|l|}
\hline & & $\begin{array}{l}\text { Sanksi Wajib } \\
\text { Pajak Badan }\end{array}$ & $\begin{array}{l}\text { Perencanaan Pajak } \\
\text { (Tax Planning) }\end{array}$ \\
\hline $\begin{array}{lll}\text { Sanksi Wajib Pajak } \\
\text { Badan }\end{array}$ & $\begin{array}{l}\text { Pearson } \\
\text { Correlation } \\
\text { Sig. (2-tailed) } \\
\text { N }\end{array}$ & 1 & $\begin{array}{l}.493^{* *} \\
.000 \\
58\end{array}$ \\
\hline $\begin{array}{l}\text { Perencanaan Pajak (Tax } \\
\text { Planning) }\end{array}$ & $\begin{array}{l}\text { Pearson } \\
\text { Correlation } \\
\text { Sig. (2-tailed) }\end{array}$ & $.493^{* *}$ & 1 \\
& N & 58 & \\
& .000 & 58 \\
\hline
\end{tabular}

Sumber : Diolah melalui program SPSS 23.0

Tabel 9. Uji Korelasi Ganda

\begin{tabular}{|c|c|c|c|c|c|c|c|}
\hline \multirow[b]{2}{*}{ Model } & \multirow[b]{2}{*}{$\mathrm{R}$} & \multirow[b]{2}{*}{$\begin{array}{c}\mathrm{R} \\
\text { Square }\end{array}$} & \multirow[b]{2}{*}{$\begin{array}{c}\text { Adjusted R } \\
\text { Square }\end{array}$} & \multirow{2}{*}{$\begin{array}{l}\text { Std. Error } \\
\text { of the } \\
\text { Estimate }\end{array}$} & \multicolumn{3}{|c|}{ Change Statistics } \\
\hline & & & & & $\begin{array}{l}\text { R Square } \\
\text { Change }\end{array}$ & \begin{tabular}{c|c|}
$F$ \\
Change \\
\end{tabular} & df1 \\
\hline 1 & .579 & .335 & .311 & 1.621 & .335 & 13.882 & 2 \\
\hline
\end{tabular}

Berdasarkan seluruh hasil data olahan melalui program SPSS 23.0 diatas diketahui bahwa korelasi baik seara parsial dan berganda berada pada korelasi hubungan sedang rentang 0,40 -0,599.

\subsection{Analisis Regresi Linear Berganda}

Tabel 10. Uji Korelasi Ganda

\begin{tabular}{|c|c|c|c|c|c|c|}
\hline & & \multicolumn{2}{|c|}{$\begin{array}{l}\text { Unstandardized } \\
\text { Coefficients }\end{array}$} & \multirow{2}{*}{$\begin{array}{c}\text { Standardized } \\
\text { Coefficients }\end{array}$} & \multirow[b]{2}{*}{$\mathrm{t}$} & \multirow[b]{2}{*}{ Sig. } \\
\hline \multicolumn{2}{|c|}{ Model } & B & Std. Error & & & \\
\hline 1 & (Constant) & 6.045 & 2.044 & & 2.958 & .005 \\
\hline & $\begin{array}{l}\text { Kepatuhan Wajib } \\
\text { Pajak Badan }\end{array}$ & .337 & .122 & .343 & 2.765 & .008 \\
\hline & $\begin{array}{l}\text { Sanksi Wajib Pajak } \\
\text { Badan }\end{array}$ & .583 & .216 & .335 & 2.704 & .009 \\
\hline
\end{tabular}

Sumber: Data diolah melalui program SPSS 23.0

$\mathrm{Y}=6,045+0,337 \mathrm{X}_{1}+0,583 \mathrm{X}_{2}$

Interpretasi :

1. Jika persepsi Kepatuhan Wajib Pajak Badan $\left(\mathrm{X}_{1}\right)$ dan Sanksi Wajib Pajak Badan $\left(\mathrm{X}_{2}\right)$ mendekati atau sama dengan 0 , maka skor Perencanaan Pajak $(\mathrm{Y})=6,045$.

Dengan interpretasi bahwa jika Kepatuhan Wajib Pajak Badan $\left(\mathrm{X}_{1}\right)$ dan Sanksi 
Wajib Pajak Badan $\left(\mathrm{X}_{2}\right)$ dianggap konstan atau tidak mengalami perubahan, maka rata-rata Perencanaan Pajak (Y) tetap sebesar 6,045.

2. Jika persepsi Kepatuhan Wajib Pajak Badan $\left(\mathrm{X}_{1}\right)$ naik satu satuan, sedangkan Sanksi Wajib Pajak Badan $\left(\mathrm{X}_{2}\right)$ tetap, maka Perencanaan Pajak (Y) akan naik sebesar 0,337 kali. Dengan interpretasi bahwa setiap peningkatan Kepatuhan Wajib Pajak Badan $\left(\mathrm{X}_{1}\right)$ sebesar 1 satuan akan berdampak peningkatan Perencanaan Pajak (Y) sebesar 0,337.

3. Jika persepsi Sanksi Wajib Pajak Badan $\left(\mathrm{X}_{2}\right)$ naik satu satuan, sedangkan Kepatuhan Wajib Pajak Badan $\left(\mathrm{X}_{1}\right)$ tetap, maka Perencanaan Pajak (Y) akan naik sebesar 0,583 kali. Dengan interpretasi bahwa setiap peningkatan Sanksi Wajib Pajak Badan $\left(\mathrm{X}_{2}\right)$ sebesar 1 satuan akan berdampak menaikan Perencanaan Pajak (Y) sebesar 0,583.

Tabel 11. Uji Koefidien Determinasi

\begin{tabular}{|l|r|r|r|r|}
\hline Model & \multicolumn{1}{|c|}{$\mathrm{R}$} & \multicolumn{1}{|c|}{$\mathrm{R}$ Square } & Adjusted R Square & $\begin{array}{c}\text { Std. Error of the } \\
\text { Estimate }\end{array}$ \\
\hline 1 & $.579^{2}$ & .335 & .311 & 1.621 \\
\hline
\end{tabular}

Sumber.: Data diolah melalui program SPSS 23.0

Berdasarkan perhitungan tabel diatas, hasil menunjukan bahwa $R$ square sebesar 0,335. Berikut perhitungan secara manual untuk mendapatkan hasil persentase koefisien determinasi :

$\mathrm{Kd}=\left(\mathrm{r}^{2}\right) \times 100 \%$

$\mathrm{Kd}=(0,335) \times 100 \%$

$\mathrm{Kd}=33,5 \%$

Hasil perhitungan koefisien determinasi diatas memiliki arti bahwa perencaan pajak dipengaruhi oleh kepatuhan dan sanksi wajib pajak badan sebesar 33,5\%, dan sisanya sebesar $66,5 \%$ dipengaruhi oleh variabel atau faktor-faktor lainnya yang tidak diteliti.

Tabel 12. Uji t

\begin{tabular}{|c|c|c|c|c|c|c|}
\hline & & \multicolumn{2}{|c|}{$\begin{array}{c}\text { Unstandardized } \\
\text { Coefficients }\end{array}$} & \multirow{2}{*}{\begin{tabular}{|c|}
$\begin{array}{c}\text { Standardized } \\
\text { Coefficients }\end{array}$ \\
Beta \\
\end{tabular}} & \multirow[b]{2}{*}{$\mathrm{t}$} & \multirow[b]{2}{*}{ Sig. } \\
\hline \multicolumn{2}{|c|}{ Model } & $\mathrm{B}$ & Std. Error & & & \\
\hline 1 & (Constant) & 6.045 & 2.044 & & 2.958 & .005 \\
\hline & $\begin{array}{l}\text { Kepatuhan Wajib } \\
\text { Paiak Badan }\end{array}$ & .337 & .122 & .343 & 2.765 & .008 \\
\hline & $\begin{array}{l}\text { Sanksi Wajib Pajak } \\
\text { Badan }\end{array}$ & .583 & .216 & .335 & 2.704 & .009 \\
\hline
\end{tabular}

Sumber: Diolah melalui program SPSS 23.0

Berdasarkan tabel diatas dapat dilihat bahwa thitung untuk variabel Kepatuhan Wajib Pajak Badan $\left(\mathrm{X}_{1}\right)$ terhadap Perencanaan Pajak (Tax Planning) (Y) sebesar 2,765 sedangkan variabel Sanksi Wajib Pajak Badan $\left(\mathrm{X}_{2}\right)$ terhadap Perencanaan Pajak (Tax Planning) (Y) sebesar 2,704. Sedangkan $t_{\text {tabel }}$ yang diperoleh berdasarkan uji dua pihak, 0,05 (5\%) taraf signifikansi dengan 58 sampel adalah sebesar 2,004 (dk =58-3). 
Tabel 13. Uji F

\begin{tabular}{|c|c|c|c|c|c|c|}
\hline Model & & $\begin{array}{r}\text { Sum of } \\
\text { Squares }\end{array}$ & $\mathrm{df}$ & $\begin{array}{c}\text { Mean } \\
\text { Square }\end{array}$ & $\mathrm{F}$ & Sig. \\
\hline \multirow[t]{3}{*}{1} & Regression & 72.991 & 2 & 36.496 & \multirow[t]{3}{*}{13.882} & \multirow[t]{3}{*}{$.000^{b}$} \\
\hline & Residual & 144.595 & 55 & 2.629 & & \\
\hline & Total & 217.586 & 57 & & & \\
\hline a. Depe & ariable: PEREN & NAAN PAJA & $T A X$ & INING) & & \\
\hline b. Predict & nstant), SAN & NAJIB PAJA & $\mathrm{BAD}$ & KEPATU & N WAJIIE & AK BADAN \\
\hline umber & liolah mel & rogram & is & & & \\
\hline
\end{tabular}

Berdasarkan tabel diatas dapat dilihat bahwa $F_{\text {hitung }}$ untuk variabel Kepatuhan Wajib Pajak Badan $\left(\mathrm{X}_{1}\right)$, Sanksi Wajib Pajak Badan $\left(\mathrm{X}_{2}\right)$ terhadap Perencanaan Pajak (Y) sebesar 13,882. Sedangkan $F_{\text {tabel }}$ yang diperoleh berdasarkan uji dua pihak, 5\% taraf signifikansi dengan 58 sampel adalah sebesar 3,16 $(\mathrm{F}(\mathrm{k} ; \mathrm{n}-\mathrm{k})=\mathrm{F}(2 ; 55)$.

\section{PENUTUP}

Berdasarkan hasil penelitian yang dilakukan mengenai Pengaruh Kepatuhan Dan Sanksi Perpajakan Terhadap Perencanaan Pajak (Tax Planning) Pada Wajib Pajak Badan Yang Terdaftar Di KPP Pratama Bandung Bojonagara maka kesimpulan dari hasil penelitian ini adalah sebagai berikut :

1. Terdapat pengaruh signifikan antara Kepatuhan wajib pajak badan $\left(\mathrm{X}_{1}\right)$ terhadap Perencanaan pajak (tax planning) (Y) pada Wajib Pajak Badan Yang Terdaftar Di KPP Pratama Bandung Bojonagara.

2. Terdapat pengaruh signifikan antara Sanksi wajib pajak badan $\left(\mathrm{X}_{2}\right)$ terhadap Perencanaan pajak (tax planning) pada Wajib Pajak Badan Yang Terdaftar Di KPP Pratama Bandung Bojonagara.

Terdapat pengaruh signifikan antara Kepatuhan Wajib Pajak Badan $\left(\mathrm{X}_{1}\right)$ dan Sanksi Wajib Pajak Badan $\left(\mathrm{X}_{2}\right)$ terhadap Perencanaan Pajak $(\mathrm{Y})$ pada Wajib Pajak Badan Yang Terdaftar Di KPP Pratama Bandung Bojonagara.

\section{DAFTAR PUSTAKA}

Chairil Anwar Pohan, 2016. Manajemen Perpajakan ; Gramedia Pustaka Utaman, Jakarta

Chaizi Nasucha, 2005. Reformasi Administrasi Publik: Teori dan Praktik; PT Gramedia Widiasarana Indonesia, Jakarta.

Devano Sony, Siti Kurnia Rahayu. 2010. Perpajakan: Konsep, Teori, dan Isu. Jakarta : Prenada Media Group.

Erly Suandy, 2011. Perencanaan Pajak; Salemba Empat

Harnanto, 2013. Perencanaan Pajak; BPFE, Yogyakarta

Irwan Wisanggeni, Michell Suharli, 2017. Manajemen Perpajakan; Mitra Wacana Media

Mardiasmo, 2016. Perpajakan; ANDI, Yogyakarta

Mohammad Zain, 2008. Manajemen Perpajakan, Salemba Empat

R. Santoso Brotodiharjo.(1991). Dasar-dasar Hukum Pajak dan Pajak Pendapatan, Erlangga, Jakarta 
Riadi, Edi. 2016. Statistika Penelitian (Analisis Manual dan IBM SPSS). Yogyakarta: CV. Andi Offset

Safri Nurmantu, 2006. Pengantar Perpajakan, Jakarta: Granit.

Siti Resmi, 2019, Perpajakan, Salemba Empat

Undang-Undang Nomor 28 tahun 2007 tentang Ketentuan Umum dan Tata cara Perpajakan

https://money.kompas.com/read/2014/01/24/16443 